\title{
Evaluation of Antimicrobial properties and nutritional potentials of Moringa oleifera Lam. leaf in South-Western Nigeria
}

\author{
Anthonia Olufunke Oluduro \\ Department of Microbiology, Faculty of Science Obafemi Awolowo University, Ile-Ife Nigeria, Nigeria \\ E.mail: aoluduro2003@yahoo.co.uk
}

Received 21 July 2011; Received in revised form 10 January 2012; Accepted 10 January 2012

\begin{abstract}
Aims: The antimicrobial activities of the leaf extract of Moringa oleifera on certain enteropathogenic and orthopaedics' wounds bacteria and fungi were investigated. Its phytochemical constituents and nutritional potentials were as well assessed.

Methodology and results: The antimicrobial activities of the leaf extracts were evaluated using paper disc diffusion method. All the leaf extracts showed little inhibitory effect on the enteropathogens, whereas aqueous and methanolic extracts showed appreciable inhibitory effects on the orthopaedic's wounds bacteria at $30 \mathrm{mg} / \mathrm{ml}$. Ethanolic extract did not show any zone of growth inhibition on the wound bacteria. All the fungal organisms except Aspergillus flavus were resistant to both aqueous and methanolic extracts of the leaf, meanwhile Ethanolic extract showed appreciable inhibitory effect on Tricophyton mentagrophyte, Pullarium sp, Aspergilus flavus and Penicillium sp. Minimum inhibitory concentration was $20 \mathrm{mg} / \mathrm{ml}$ on all the enteropathogens and ranged from 3.75 to $30 \mu \mathrm{g} / \mathrm{ml}$ on the orthopaedics' wounds organisms. Phytochemical analysis revealed less than $1 \%$ of alkaloids, tannin, flavonoids and phenol in the leaf and contained appreciable quantity of calcium, magnesium, iron and $45.4 \%$ carbohydrate, $16.2 \%$ protein and $9.68 \%$ fibre.

Conclusion, significance and impact of study: The study showed that Moringa oleifera leaves possess inhibitory properties thus can serve as an alternative therapy for wounds and certain fungal infections and also a good source of nutrient supplements.
\end{abstract}

Key words: Moringa leaf, antimicrobial activity, bacteria, fungi.

\section{INTRODUCTION}

The leaves of Moringa oleifera Lam. are eaten in African countries, such as Ghana, Ethiopia, Nigeria, East Africa and Malawi. Moringa tree is cultivated for foods and medicinal purposes (Olson, 2002). Moringa leaf is a natural antihelmintic, antibiotic, detoxifer, outstanding immune builder used in some countries for the treatment of malnutrition and malaria (Thilza et al., 2010). All parts of the Moringa tree are edible and have long been consumed by humans. According to Fugile (2000), the many uses of Moringa include: alley cropping (biomass production), animal forage (leaves and treated seedcake), biogas (leaves), fertilizer (seed-cake), foliar nutrient (juice expressed from leave), green manure (from leaves), gum (from tree trunks), honey and sugar cane juice-clarifier (powdered seed), honey (flower nectar) and medicine (all plant parts). Moringa leaves are known to have a high content of protein, minerals and vitamin, hence an ideal nutritional supplement, (Fletcher, 1998). Moringa leaves have been used to combat malnutrition, especially among infants and nursing mothers and hasten uterine contraction during child birth in pregnant women. It's antihypertensive, diuretic, antispasmodic, antiulcer, anti cancer and cholesterol lowering activities have been reported (Cáceres, 1992; Dangi et al., 2002; Fahey et al.,
2004).The leaves and pods are helpful in increasing breast milk in nursing mothers during breastfeeding and leaf decoction has been found useful in the treatment of asthma, back pain and rheumatism. $M$. oleifera tree has in recent times been advocated as an outstanding indigenous source of highly digestible protein, carotenoids and vitamin $\mathrm{C}$ suitable for utilization in many of the so called developing regions of the world where undernourishment is a major concern (Fugile, 2001). In some parts of the world for example Senegal and Haiti, health workers have been treating malnutrition in small children, pregnant and nursing women with Moringa leaf powder (Price, 1985). Caceres et al. (1992) reported antiinflammatory activity from the hot water infusions of flowers, leaves, roots, seeds and stalks or bark of $M$. oleifera using carrageenan-induced hind paw edema in rats. The antioxidant activity of various extracts of $M$. oleifera leaf has been reported by several other authors (Bajpai et al., 2005; Sreelatha and Padma, 2009; Sultana et al., 2009; Singh et al., 2009). However, much has not been reported on the antibacterial healing property of $M$. oleifera leaf. The present study therefore reported the antimicrobial activity of $M$. oleifera leaf on some enteropathogens and orthopaedics' wounds bacterial and fungal organisms as well as its nutritional potentials.

*Corresponding author 


\section{MATERIALS AND METHODS}

\section{Plant materials}

Fresh leaves of $M$. oleifera were plucked from the Moringa tree growing in front of the Department of Chemical Engineering, Obafemi Awolowo University, IleIfe, Nigeria. The leaves were identified and confirmed at the Botany Department of the University.

\section{Microorganisms}

Pure culture of microorganisms used for the evaluation of the antimicrobial potential of the leaves extracts include enteropathogenic (Escherichia coli, Salmonella typhi, Staphylococcus aureus, Enterococcus sp. and Pseudomonas aeruginosa) and orthopaedics's wounds bacterial (Klebsiella pneumoniae, Proteus vulgaris, Providencia stuartii, Escherichia coli, Streptococcus sp, Pseudomonas fluorescens, Acinetobacter baumanii, Burkholderia cepacia, Yersinia enterocolitica, Proteus mirabilis, Serratia rubidae, Salmonella pullorum, and Klebsiella oxycota) and fungal isolates which include Aspergillus flavus, candida albicans, Penicillium sp, Pullarium sp, Trichophyton mentagrophyte, Fusarium $s p$ and Trichophyton sp.The enteropathogenic bacterial isolates were all locally isolated pure cultures (LIO) obtained from the culture collection unit of Obafemi Awolowo University, Ile-Ife, Nigeria, while the orthopaedic bacterial isolates were isolated from the wounds of some orthopaedic in-patients of the Obafemi Awolowo University Teaching Hospital, Ile-Ife, Nigeria. Wounds samples of the patients were cultured on MacConkey and nutrient agar. The isolates were identified using various standard biochemical tests described by Olutiola et al., (1991). The fungal isolates were isolated from the air of Sawmill environment in Ile-Ife, Nigeria, on Potato dextrose agar. All bacterial isolates were maintained on nutrient agar slants and fungal isolates on Potato dextrose agar at temperature of $4{ }^{\circ} \mathrm{C}$.

\section{Plant extraction}

One hundred grams of fresh leaves of $M$. oleifera Lam. were shade dried at room temperature $\left(32-35{ }^{\circ} \mathrm{C}\right)$ to constant weight over a period of 5 days. The dried leaves were ground into powdered using a mortar and pestle. 25 $\mathrm{g}$ of the powdered leaves were separately extracted in $500 \mathrm{ml}$ conical flasks with $100 \mathrm{ml}$ of deionised distilled water (aqueous extraction), $60 \%$ methanol (methanolic extraction), and $90 \%$ ethanol (ethanolic extraction).The conical flasks were plugged with rubber corks, then shaken at $120 \mathrm{rpm}$ for $30 \mathrm{~min}$ and allowed to stand at room temperature for 5 days with occasional manual agitation of the flask using a sterile glass rod at every 24 hour. The extracts were separately filtered using sterile Whatman no. 1 filter paper. The resulting filtrates were then concentrated in a rotary evaporator and subsequently lyophilized to dryness.

\section{Antimicrobial activity assay}

Antimicrobial activity of the aqueous, ethanolic and methanolic extracts of the leaves was assayed using the paper disc diffusion method (Oluma et al., 1984, Doughari et al., 2007). The concentrated leaf extracts were dissolved in $5 \%$ dimethyl sulfoxide (DMSO) and sterile discs $(6 \mathrm{~mm}$, Hi-media, india) were each impregnated with $30 \mu \mathrm{l}$ of $30 \mathrm{mg} / \mathrm{ml}$ of each extract. The discs were carefully and firmly placed on the Muller Hinton Agar (MHA) plates earlier seeded with standardized bacterial suspensions (approximately $1.5 \times 106 \mathrm{cfu} / \mathrm{ml}$ ). Paper discs impregnated with $30 \mu \mathrm{l}$ of a solution of $30 \mathrm{mg} / \mathrm{ml}$ of the following standard antibiotics; ciprofloxacin, amoxicillin, gentamicin and erythromycin were used as control for comparison. Filter paper discs dipped into sterile distilled water and allowed to dry were used as control. The plates were then incubated at $37{ }^{\circ} \mathrm{C}$ for $24 \mathrm{~h}$. Antibacterial activity was determined by measurement of zone of inhibition around each paper disc.

\section{Determination of Minimum Inhibitory Concentration (MIC)}

The MIC of the aqueous and methanolic extracts of the leaves extracts was determined as described by Akinpelu and Kolawole (2004). Two-fold serial dilutions of the plant extracts were prepared, from which $2 \mathrm{mls}$ aliquots was taken and added to $18 \mathrm{ml}$ of pre-sterilized molten nutrient agar at a temperature of $40{ }^{\circ} \mathrm{C}$. The media were then poured into sterile Petri dishes and allowed to solidify. The surfaces of the media were allowed to dry before streaking with $18 \mathrm{~h}$ old cultures of the test bacterium. The plates were later incubated in an incubator at $37{ }^{\circ} \mathrm{C}$ for up to $72 \mathrm{~h}$ after which they were examined for the presence or absence of growth. The MIC was taken as the lowest concentration that prevented bacterial growth.

\section{Phytochemical, mineral and proximate anlaysis}

Phytochemical analysis for qualitative detection of alkaloids, tannin, saponin, flavonoids and phenol was performed on the extracts as follows:

\section{Determination of Saponins}

The ability of saponins to produce frothing in aqueous solution was used as screening test for saponins. About $0.5 \mathrm{~g}$ of each plant extract was shaken with distilled water in a test tube, frothing which persisted on warming was taken as evidence for the presence of saponins (Sofowora, 1982).

\section{Determination of Tannins}

Five grams of each portion of plant extract was stirred with $100 \mathrm{ml}$ of distilled water, filtered and ferric chloride reagent added to the filtrate. A blue-black green precipitate indicated the presence of tannins (Trease and Evans, 1978). 


\section{Determination of Flavoniods}

Ten grams of the plant samples were extracted with $60 \mathrm{ml}$ of $80 \%$ aqueous methanol at room temperature. The whole solution was filtered through whatman filter paper. The filtrate was later transferred into a crucible and evaporated to dryness over a water bath and weighed (Edeoga et al., 2005).

\section{Test for alkaloids}

A $0.5 \mathrm{~g}$ of extract was diluted with $10 \mathrm{ml}$ of acid alcohol, boiled and filtered. Two milliliter of diluted ammonia was added to $5 \mathrm{ml}$ of the filtrate. Five milliliter of chloroform was added and shaken gently to extract the alkaloidal base. The chloroform layer was extracted with $10 \mathrm{ml}$ of acetic acid. This was divided into two portions. Meryer's reagent was added to one portion and Draggendorff's reagent to the other. The formation of a cream (with Meryer's reagent) or reddish brown precipitate (with Draggendorff's reagent) was taken as positive for the presence of alkaloid (Trease and Evans, 1983).

\section{Test for flavonoids}

A $2 \mathrm{~g}$ of powdered sample was detanned with acetone. The sample was placed on a hot water bath for all traces of acetone to evaporate. Boiling distilled water was added to the detanned sample. The mixture was filtered while hot. The filtrate was cooled and $5 \mathrm{ml}$ of $20 \%$ sodium hydroxide was added to equal volume of the filtrate. A yellow solution indicates the presence of flavonoids (Trease and Evans, 1989; Sofowora, 1983).

\section{Mineral analysis}

Mineral content was determined by Association of Official Analytical Chemists methods (AOAC, 1990) using the flame system of the atomic absorption spectrophotometry (AAS), (Varian SpectrAA 220, USA). Moringa leaves were ashed at $550^{\circ} \mathrm{C}$ overnight and the ash was dissolved in concentrated nitric acid and filtered, diluted to $50 \mathrm{~mL}$ with deionized water and the absorbance of the samples was read directly on the AAS. Working standard solutions of calcium $(\mathrm{Ca})$, potassium $(\mathrm{K})$ and iron $(\mathrm{Fe})$ were prepared from stock standard solution (1000 ppm), in $2 \mathrm{~N} \mathrm{HNO} 3$ and absorbance was noted for standard solution of each element and samples using atomic absorption spectrophotometer (AAS). The calibration curves obtained for concentration vs. absorbance. Data were statistically analyzed using fitting of straight line by least square method. A blank reading was also taken and necessary corrections were made during the calculation of concentration of various elements.

\section{Proximate analysis}

Proximate analysis including the percentage of moisture content, crude protein, crude fat, ash contents and crude fibre in the sample were determined using The
Association of Official Analytical Chemists methods (AOAC, 1990).

Moisture content: The aluminium dish was placed inside drying oven for $105{ }^{\circ} \mathrm{C}$ for $2 \mathrm{~h}$. After which the crucible was placed in the desiccators to allow cooling. The aluminium dish was weighed and $2 \mathrm{~g}$ of the powder was placed in the aluminium dish. The sample was dried in drying oven (Memmert 600, Germany) for $3 \mathrm{~h}$ at $105{ }^{\circ} \mathrm{C}$ and then weighed to determine the percentage of dry weight and the percentage of moisture content.

Ash: The preparation for ash analysis was the same as that for moisture content. Two grams of sample was put into crucible, the weight recorded and placed in muffle oven (Furnace Nabertherm, Germany) at $550^{\circ} \mathrm{C}$ for $8 \mathrm{~h}$.

Fat: The fat content was determined by directly extracting the sample with petroleum ether in an intermittent Soxhlet extractor (Soxhlet Extractor Gerhadt, Germany) for $4 \mathrm{~h}$. The residue in round bottom flask after solvent removal represents the fat content of the sample.

Crude protein: The crude protein content of the samples was estimated by macro-Kjeldahl method, in which the sample was digested with a known quantity of acid. The digested material was distilled after the addition of alkali. The release ammonia was collected in $4 \%$ boric acid. The resultant boric acid which now contained the ammonia released was then titrated against $0.1 \mathrm{~N} \mathrm{HCl}$. The percentages of nitrogen were converted to protein by multiplying by 6.25 .

Crude fibres: Two grams of sample was put into $250 \mathrm{~mL}$ conical flask and $1.25 \%$ Sulphuric acid solution was added. The sample was heated for about $30 \mathrm{~min}$, filtered then washed until traces of acid could not be detected using $\mathrm{pH}$ paper. The Whatman paper 5B with 125 micrometer pore size was placed in the Buchner flask. The acid extracted was transferred into $250 \mathrm{~mL}$ conical flask and $1.25 \% \mathrm{NaOH}$ solution was added subsequently. The sample was heated again for $30 \mathrm{~min}$, filtered using vacuum filter and washed with water until base was undetected. The whole material was transferred into crucible and dried for $12 \mathrm{~h}$ at $120{ }^{\circ} \mathrm{C}$. After that the crucible was placed into muffle oven at $550{ }^{\circ} \mathrm{C}$ for $12 \mathrm{~h}$ and weight of crucible was recorded. (Jongrungruangchok et al., 2010)

\section{RESULTS}

The antibacterial activity of the aqueous, methanolic and ethanolic extracts of $M$. oleifera leaves is presented in Table 1. All the leaf extracts showed little inhibitory effect on the enteropathogens at extract concentration of 30 $\mathrm{mg} / \mathrm{ml}$ with zone of growth inhibition of less than $1.5 \mathrm{~mm}$. However, all the orthopaedics' wounds isolates except Streptococcus $s p$ and $P$. mirabilis were sensitive to the aqueous extract of the leaves with zones of growth inhibition ranging from 12 to $15 \mathrm{~mm}$, meanwhile 
Mal. J. Microbiol. Vol 8(2) 2012, pp. 59-67

Table 1: Antibacterial activity of Moringa oleifera leaves

\begin{tabular}{|c|c|c|c|c|}
\hline \multirow[t]{2}{*}{$\begin{array}{l}\text { Source of } \\
\text { Organisms }\end{array}$} & \multirow[t]{2}{*}{ Organisms } & $\begin{array}{c}\text { Aqueous } \\
\text { extract } \\
(30 \mathrm{mg} / \mathrm{ml})\end{array}$ & $\begin{array}{c}\text { Methanolic } \\
\text { extract } \\
(30 \mathrm{mg} / \mathrm{ml})\end{array}$ & $\begin{array}{c}\text { Ethanolic } \\
\text { extract } \\
(30 \mathrm{mg} / \mathrm{ml})\end{array}$ \\
\hline & & \multicolumn{3}{|c|}{ Diameter of zone of inhibition (mm) } \\
\hline & Escherichia coli (LIO) & 0.20 & 1.10 & 1.00 \\
\hline \multirow{8}{*}{ Enteropathogens } & Salmonella typhi (LIO) & 0.50 & 0.95 & 1.20 \\
\hline & Staphylococcus aureus(LIO) & 0.10 & 0.65 & 0.95 \\
\hline & Enterococcus sp. (LIO) & 0.10 & 0.70 & 0.65 \\
\hline & Pseudomonas aeruginosa(LIO) & 0 & 0.45 & 0.30 \\
\hline & Klebsiella pneumoniae & 12.00 & 0 & 0 \\
\hline & Proteus vulgaris & 15.00 & 0 & 0 \\
\hline & Providencia stuartii & 14.00 & 0 & 0 \\
\hline & Escherichia coli & 15.00 & 0 & 0 \\
\hline Orthopaedics' & Streptococcus sp. & 0 & 15.00 & 0 \\
\hline \multirow{8}{*}{ wounds } & Pseudomonas fluorescens & 13.00 & 17.00 & 0 \\
\hline & Acinetobacter baumanii & 12.00 & 14.00 & 0 \\
\hline & Burkholderia cepacia & 12.00 & 19.00 & 0 \\
\hline & Yersinia enterocolitica & 15.00 & 19.00 & 0 \\
\hline & Proteus mirabilis & 0 & 13.00 & 0 \\
\hline & Serratia rubidae & 15.00 & 0 & 0 \\
\hline & Salmonella pullorum & 15.00 & 12.00 & 0 \\
\hline & Klebsiella oxycota & 14.00 & 0 & 0 \\
\hline
\end{tabular}

(LIO): Locally isolated organism

Table 2: Antifungal activity of Moringa oleifera leaves extracts

\begin{tabular}{|c|c|c|c|c|}
\hline Fungal isolates & $\begin{array}{l}\text { Aqueous extract } \\
(30 \mathrm{mg} / \mathrm{ml})\end{array}$ & $\begin{array}{l}\text { Methanolic extract } \\
(30 \mathrm{mg} / \mathrm{ml})\end{array}$ & $\begin{array}{l}\text { Ethanolic extract } \\
(30 \mathrm{mg} / \mathrm{ml})\end{array}$ & $\begin{array}{l}\text { Control Ketoconazole } \\
(30 \mathrm{mg} / \mathrm{ml})\end{array}$ \\
\hline & \multicolumn{4}{|c|}{ Diameter of Zone of inhibition $(\mathrm{mm})$} \\
\hline Aspergillus flavus & 0 & 12.0 & 15.0 & 5 \\
\hline Candida albicans & 5.0 & 0 & 3.0 & 6 \\
\hline Penicillium carmenberti & 0 & 0 & 15.0 & 4 \\
\hline Pullarium $s p$ & 5.0 & 0 & 20.0 & ND \\
\hline $\begin{array}{l}\text { Trichophyton } \\
\text { mentagrophyte }\end{array}$ & 0 & 0 & 22.0 & ND \\
\hline Fusarium sp & 0 & 0 & 0 & 12 \\
\hline Trichophyton sp & 0 & 0 & 0 & ND \\
\hline
\end{tabular}

(ND): not determined

methanolic extract produced inhibition zones ranging from 12 to $19 \mathrm{~mm}$ with Streptococcus sp, $P$. fluorescens, $A$. baumanii, $B$. cepacia, $Y$. enterocolitica, $P$. mirabilis and $S$. pullorum but did not inhibit $K$. pneumoniae, $P$. vulgaris, $P$. stuartii, E. coli (ATCC2592), S. rubidae and K. oxycota. However, all the orthopaedics' wounds organisms developed resistance to the ethanolic extract of the leaves.

The antifungal activity of the leaves extracts is presented in Table2. All the fungal organisms developed resistance to both the aqueous and methanolic extracts of the leaves, except $A$. Flavus which was sensitive to methanolic extract with zone of growth inhibition of $12 \mathrm{~mm}$ at extract concentration of $30 \mathrm{mg} / \mathrm{ml}$. However, the ethanolic extract inhibited the growth of some of the fungal organisms producing zone of growth inhibition of $22 \mathrm{~mm}$ against $T$. mentagrophyte, $20 \mathrm{~mm}$ on Pullarium $\mathrm{sp}$ and $15 \mathrm{~mm}$ each against $A$. flavus and Penicillium sp.
Minimum inhibitory concentration was $20 \mathrm{mg} / \mathrm{ml}$ on all the enteropathogens and ranged from 3.75 to $30 \mu \mathrm{g} / \mathrm{ml}$ on the orthopaedics' wounds organisms (Table 3 ).

The susceptibility of the bacterial isolates to the reference antibiotics is presented in Table 4. Some of the enteropathogens and orthopaedics' wounds organisms developed resistance to either one or two of the reference antibiotics. Meanwhile some of the bacterial isolates were sensitive to the leaves extracts but resistant to the reference antibiotics. Similarly, the antimicrobial activity of the leaves extracts were comparable to the reference antifungal ketoconazole used (Table 2).

Phytochemical screening and quantitative estimation of the percentage crude yields of chemical constituents revealed that alkaloids, tannin, flavonoids and phenol were less than $1 \%$, while saponin constituted $18.34 \%$. Meanwhile, steroid, terpenoids and cardiac glycosides were absent (Table 5). 
Mal. J. Microbiol. Vol 8(2) 2012, pp. 59-67

Table 3: Minimum Inhibitory Concentration of $M$. oleifera leaves extract

\begin{tabular}{|c|c|c|c|c|}
\hline \multirow[b]{2}{*}{$\begin{array}{l}\text { Source of } \\
\text { Organisms }\end{array}$} & \multirow[b]{2}{*}{ Organisms } & \multicolumn{3}{|c|}{ Minimum inhibitory concentration $(\mathrm{mg} / \mathrm{ml})$} \\
\hline & & $\begin{array}{c}\text { Aqueous } \\
\text { Extract }\end{array}$ & $\begin{array}{l}\text { Methanolic } \\
\text { Extract }\end{array}$ & $\begin{array}{l}\text { Ethanolic } \\
\text { Extract }\end{array}$ \\
\hline \multirow{6}{*}{$\begin{array}{l}\text { Enteropath } \\
\text { ogens }\end{array}$} & Escherichia coli (LIO) & 20 & 20 & 20 \\
\hline & Salmonella typhi (LIO) & 30 & 30 & 20 \\
\hline & Staphylococcus aureus (LIO) & 30 & 20 & 20 \\
\hline & Enterococcus sp. (LIO) & 20 & 20 & 20 \\
\hline & Pseudomonas aeruginosa (LIO) & - & 30 & 30 \\
\hline & \multicolumn{4}{|c|}{ Minimum inhibitory concentration $(\mu \mathrm{g} / \mathrm{ml})$} \\
\hline \multirow{13}{*}{$\begin{array}{l}\text { Orthopaedics' } \\
\text { wounds }\end{array}$} & Klebsiella pneumonia & - & - & - \\
\hline & Proteus vulgaris & 30 & 30 & 30 \\
\hline & Providencia stuartii & - & - & - \\
\hline & Escherichia coi(ATCC2592) & - & - & - \\
\hline & Streptococcus sp. & - & - & - \\
\hline & Pseudomonas fluorescens & 30 & 30 & 30 \\
\hline & Acinetobacter baumanii & 7.5 & 15 & 15 \\
\hline & Burkholderia cepacia & - & - & - \\
\hline & Yersinia enterocolitica & 30 & - & - \\
\hline & Proteus mirabilis & 3.75 & 3.75 & 3.75 \\
\hline & Serratia rubidae & - & - & - \\
\hline & Salmonella pullorum & 30 & 30 & 30 \\
\hline & Klebsiella oxycota & - & - & - \\
\hline
\end{tabular}

(-): resistance

(LIO): Locally isolated organism

Table 4: Zones of antibacterial inhibition of reference antibiotics

\begin{tabular}{|c|c|c|c|c|}
\hline \multirow[t]{2}{*}{ Organisms } & \multicolumn{4}{|c|}{$\begin{array}{l}\text { Diameter of zones of } \\
\text { inhibition }(\mathrm{mm}) \\
\text { Concentration of } \\
\text { antibiotics }(30 \mathrm{mg} / \mathrm{ml})\end{array}$} \\
\hline & GEN & AMX & CPX & ERY \\
\hline Escherichia coli (LIO) & 15 & 15 & 24 & $\mathrm{R}$ \\
\hline Salmonella typhi (LIO) & 10 & 18 & 36 & $\mathrm{R}$ \\
\hline $\begin{array}{l}\text { Staphylococcus aureus } \\
\text { (LIO) }\end{array}$ & 16 & 12 & 23 & 15 \\
\hline Enterococcus sp. (LIO) & $\mathrm{R}$ & ND & ND & $\mathrm{R}$ \\
\hline $\begin{array}{l}\text { Pseudomonas aeruginosa } \\
\text { (LIO) }\end{array}$ & $\mathrm{R}$ & $\mathrm{R}$ & 16 & $\mathrm{R}$ \\
\hline Klebsiella pneumoniae & 11 & 15 & 15 & ND \\
\hline Proteus vulgaris & 5 & 15 & 15 & ND \\
\hline Providencia stuartii & & $\mathrm{R}$ & 15 & 15 \\
\hline $\begin{array}{l}\text { Escherichia } \\
\text { coli(ATCC2592) }\end{array}$ & 15 & 15 & 15 & ND \\
\hline Streptococcus sp. & $\mathrm{R}$ & 15 & 15 & 15 \\
\hline Pseudomonas fluorescens & $\mathrm{R}$ & $\mathrm{R}$ & $\mathrm{R}$ & ND \\
\hline Acinetobacter baumanii & 15 & 15 & 15 & ND \\
\hline Burkholderia cepacia & $\mathrm{R}$ & $\mathrm{R}$ & $\mathrm{R}$ & ND \\
\hline Yersinia enterocolitica & $\mathrm{R}$ & $\mathrm{R}$ & $\mathrm{R}$ & ND \\
\hline Proteus mirabilis & $\mathrm{R}$ & $\mathrm{R}$ & $\mathrm{R}$ & ND \\
\hline Klebsiella oxycota & 17 & 15 & 15 & ND \\
\hline Salmonella pullorum & 13 & 15 & 15 & ND \\
\hline
\end{tabular}

(Table 6), while Table 7 presents the percentage crude proximate composition of the various nutrients. The leaf contained $45.4 \%$ carbohydrate, $16.2 \%$ protein and 9.68 $\%$ fibre.

\section{DISCUSSION}

The leaves extract demonstrated weak antibacterial activity on the enteropathogens as the growth inhibition zones were less than $1.5 \mathrm{~mm}$. This indicates that $M$. oleifera leaf has little effect on these organisms at the concentration used. However, both the aqueous and methanolic extracts of the leaf showed appreciable antibacterial activity on the orthopaedics' wounds organisms, indicating its high antibacterial potential and effectiveness in the treatment of wound infections.In concordance with Rathi et al. (2006) who evaluated wound healing property from the aqueous extract of leaves of $M$. oleifera on male Swiss albino mice and reported significant increase in wound closure rate, skin breaking strength, granuloma breaking strength, hydroxyproline content, granuloma dry weight and decrease in scar area. Similarly, Hukkeri et al. (2006) investigated antipyretic and wound healing activity from the ethanolic and ethyl acetate extracts of $M$. oleifera leaves and reported that the ethanolic and ethyl acetate extracts of seeds showed significant antipyretic activity in rats, whereas ethyl acetate extract of dried leaves showed significant wound healing activity (10\% extracts in the form of ointment) on excision, incision and dead space (granuloma) wound models in rats. In the present study, the ethanolic extract of $M$. oleifera leaf showed significant antifungal activity particularly on $A$. flavus, Penicillium sp,Pullarium $\mathrm{sp}$ and $T$. mentagrophyte, 
whereas aqueous and methanolic extracts did not show any antifungal effect, except on $A$. flavus methanolic extract where a zone of growth inhibition of $12 \mathrm{~mm}$ was developed with metanolic extract. These findings corroborate with previous reports (Dahot, 1998; Rahman et al., 2009; Bukar et al., 2010). Ethanolic extract produced antifungal growth inhibition zone of $22 \mathrm{~mm}$ with T. mentagrophytes, thus agrees with Chuang et al. (2007) who reported in vitro antifungal activity from the ethanolic extracts of the leaves of $M$. oleifera against dermatophytes such as $T$. rubrum, $T$. mentagrophytes, $E$. Xoccosum, and M. canis. Similarly, Nwosu and Okafor (1995) reported antifungal activity of $M$. oleifera against seven pathogenic fungi of which the extracts were effective against $T$. rubrum and $T$. mentagraphytes. The study also concurs with Rahman et al. (2009) who in their investigation on the antibacterial activity of leaf juice and extracts of $M$. oleifera against human pathogenic bacteria reported that the fresh leaf juice $(10 \mu \mathrm{l})$, powder from fresh leaf juice, cold water extract of fresh leaf, $1175 \mu \mathrm{g}$ disc-1, displayed a potential antibacterial activity against all the tested four Gram negative bacteria (Shigella shinga, $P$. aeruginosa, $S$. sonnei and Pseudomonas spp.) and six Gram-positive bacteria ( $S$. aureus, B. cereus, Streptococcus-B- haemolytica, B. subtilis, S. lutea and B. megaterium).

Table 5: Phytochemical Analysis of Moringa oleifera leaves

\begin{tabular}{lc}
\hline Component & \% composition \\
\hline Alkaloids & 0.4 \\
Tannin & 0.33 \\
Saponin & 18.34 \\
Steroid & - \\
Terpenoids & - \\
Flavonoids & 0.77 \\
Cardiac glycosides & - \\
Phenol & 0.29 \\
\hline "_": not present &
\end{tabular}

"-": not present

Table 6: Mineral Composition of Moringa oleifera leaves

\begin{tabular}{lc}
\hline Minerals & Concentration $(\mathbf{p p m})$ \\
\hline Sodium & 11.86 \\
Potassium & 25.83 \\
Calcium & 98.67 \\
Magnesium & 107.56 \\
Zinc & 148.54 \\
Iron & 103.75 \\
Manganese & 13.55 \\
Copper & 4.66 \\
Lead & 2.96 \\
\hline
\end{tabular}

Table 7: Proximate Analysis of Moringa oleifera leaves

\begin{tabular}{lc}
\hline Nutrients & \% composition \\
\hline Carbohydrate & 45.43 \\
Protein & 16.15 \\
Fat & 6.35 \\
Fibre & 9.68 \\
Moisture & 11.76 \\
Ash & 10.64 \\
\hline
\end{tabular}

The finding of this study is however at variance with Doughari et al. (2007) who reported in their study on the antibacterial activity from the aqueous, acetone and ethanolic extracts of the leaves of $M$. oleifera that ethanolic extract of the plant demonstrated the highest activity, while the aqueous extract showed the least activity at $100 \mathrm{mg} / \mathrm{ml}$. In this study ethanolic extract did not exhibit antimicrobial activity on the tested orthopaedics' wounds organisms but showed insignificant effect on the enteropathogens at the extract concentration of $30 \mathrm{mg} / \mathrm{ml}$. The methanolic extract showed better and greater inhibitory property on both the enteropathogens and the orthopaedics' wounds organisms, than aqueous extract, thus making the solvent as the best medium for the extraction of the active components of the leaf. It has been reported that different solvents have different extraction capabilities and spectrum of solubility for the phytoconstituents (Majorie, 1999; Srinvasan et al. 2001). Meanwhile It is clearly noted that aqueous extract of $M$. oleifera leaf posses significant antimicrobial activity against both Gram negative and Gram positive bacterial organisms from wounds, thus signalling its broad spectrum of antibacterial activity.

Moreover, aqueous extract inhibited almost all the test organisms, thus rendering water as well as a good solvent of extraction for the leaves, much so, that most people who use this leaf as a traditional mean of treatment of various skin ailments and other diseases make use of water-based extract of the leaf. The variations in the findings of this study compared to earlier studies reported may be due to climatic factor as it affects the plants, soil conditions of the geographical locations, solvents used etc. Previous studies (Alade and Irobi 1993; Iwu 2000) have demonstrated the antimicrobial activities of the constituent of some flowering plants. These studies however elucidate the major problem with this type of research, namely the lack of uniformity in the criteria selected to study the activity. This has in the past lead to relevant contradictions between the results obtained by different groups and even for the same. Authors study the same sample with different methods. To try to solve this problem, Rios et al. (1998) published a review of the experimental methods used for studying the activity of both plant extracts and essential oils to date. They proposed the use of diffusion methods for studying polar compounds of small or medium molecular size and for determining the antimicrobial spectrum because this method allows researchers to test different compound against one microorganism. The solid dilution method was recommended for studying polar and non-polar substances are well as all types of complex extracts. This method is especially good for determining the relative potency of extracts or essential oils and for establishing their antimicrobial spectrum as it facilitates the use of different strains against the extracts on the same plate. Finally, liquid dilution method is the best way to establish the real potency of a pure compound, but solubility is an obvious requisite. 
The activity of $M$. oleifera leaf extracts was comparable to those of antibacterial antibiotics ciprofloxacin, amoxicillin, gentamicin and erythromycin and antifungal drug ketoconazole. Phytochemically, the study revealed the presence of certain phytoconstituents. Meanwhile, several authors have characterised and reported several chemical compounds present in the leaf. Faizi et al. (1994) reported the isolation of two nitrile glycosides from the ethanolic extracts of $M$. oleifera leaf, niazirin and niazirinin and three mustard oil glycosides, 4-[(4'-Oacetylalpha-L- rhamnosyloxy) benzyl]isothiocyanate, niaziminin A, and niaziminin. Faizi et al. (1995) isolated six new and three synthetically known glycosides from the leaf of $M$. oleifera. Most of these compounds, bearing thiocarbamate, carbamate or nitrile groups, are fully acetylated glycosides, which are very rare in nature.

Murakami et al. (1998) isolated niaziminin, a thiocarbamate from the leaves of $M$. oleifera. Bennett et al. (2003) isolated various glucosinolates and phenolic compounds from various parts of $M$. oleifera. The seeds only contained 4-(alpha-I-rhamnopyranosyloxy)benzylglucosinolate at high concentrations. Roots of $M$. Oleifera contain high concentrations of both 4-(alpha-Irhamnopyranosyloxy) benzylglucosinolate and benzyl glucosinolate. Leaves of the plant contains 4-(alpha-lrhamnopyranosyloxy)-benzylglucosinolate and three monoacetyl isomers of this glucosinolate. Only 4-(alpha-Irhamnopyranosyloxy)-benzylglucosinolate was detected in M. oleifera bark tissue.

The leaves has been also reportedly found to contain quercetin-3-O-glucoside and quercetin-3-O-(6"- malonylglucoside), and lower amounts of kaempferol-3-Oglucoside and kaempferol-3-O-(6"-malonyl-glucoside), 3caffeoylquinic acid and 5-caffeoylquinic acid (Bennett et al., 2003).

Siddhuraju and Becker (2003) reported quercetin and kaempferol from the ethanolic extracts of freeze-dried leaves of $M$. oliefera. Isolation of five flavonol glycosides characterised as kaempferide 3-O-(2",3"diacetylglucoside), $\quad$ kaempferide 3-O-(2"Ogalloylrhamnoside), kaempferide 3-O-(2"-Ogalloylrutinoside)-7-O-alpha-rhamnoside kaempferol 3-O[beta-glucosyl-(1 $\rightarrow$ 2)]-[alpha-rhamnosyl-(1 $\rightarrow$ 6)]-betaglucoside-7-Oalpharhamnoside and kaempferol 3-O[alpha-rhamnosyl-(1 $\rightarrow$ 2)]-[alpha-rhamnosyl-(1 $\rightarrow 4)$ ]betaglucoside-7-O-alpha-rhamnoside together with benzoic acid 4-O-beta-glucoside, benzoic acid 4-O-alpharhamnosyl-(1 $\rightarrow$ 2)-beta-glucoside and benzaldehyde 4O-beta-glucoside have been reported from the methanolic extract of $M$. oleifera leaf. Also obtained from the same extract were known compounds, kaempferol 3-O-alpharhamnoside, kaempferol, syringic acid, gallic acid, rutin and quercetin 3-O-beta-glucoside. Singh et al. (2009) reported presence of gallic acid, chlorogenic acid, ellagic acid, ferulic acid, kaempferol, quercetin and vanillin from the aqueous extracts of leaves, fruits and seeds of M.oliefera. Phytochemically, it is known as rich source of glycosides, phenols, sterols, flavanol glycosides present in $M$. oleifera might be medicinally important and/or nutritionally valuable (Mishra et al., 2011).

Elemental and proximate analysis of the various crude nutrients present in the leaf revealed that the leaves contain an appreciable amount of nutrients and can be included in diets to supplement human's daily nutrient needs. Similar findings have been reported (Oduro et al., 2008, Fuglie, 2001; Nutritional Value of Malunggay Pods/Leaves, 2006).

\section{CONCLUSION}

The leaf extracts showed an appreciable inhibitory activity against the orthopaedics' wounds bacterial isolates and certain fungal organisms tested which implies its effectiveness in infection therapy particularly those caused by the organisms under study, The phytochemical constituents can be investigated further to achieve lead molecules in the search of novel herbal drugs.

\section{ACKNOWLEDGEMENTS}

I sincerely acknowledge the contribution of Miss Abimbola Olabintan, an ex-student of the Department of Microbiology, University of Ado-Ekiti, Nigeria and $\mathrm{Mr}$ Opeyemi Alao who is also an ex-student of the Department of Microbiology, Obafemi Awolowo University, Ile-Ife, Nigeria.

\section{REFERENCES}

Akinpelu, D. A. and Kolawole, D. O. (2004). Phytochemcials and antimicrobial activity of leaf extract of Piiositigma thoriningi (Schum). Science Focus 7: 64-70.

Alade, P. I. and Irobi, O. N. (1993). Antimicrobial Activities of Crude Leaf Extracts of Acalypha wilkesiana. Journal of Ethnopharmacology 39: 171174.

AOAC, (1990). AOAC, Official Methods of Analysis. Gaithersburg, 15th ed. MD, USA, Association of Official Analytical Chemists, Arlington, VA.

Bajpai, M., Pande, A., Tewari, S. K. and Prakash, D. (2005). Phenolic contents and antioxidant activity of some food and medicinal plants. International Journal of Food Science and Nutrition 56(4): 287291.

Bennett, R. N., Mellon, F. A., Foidl, N., Pratt, J. H., Dupont, M. S., Perkins, L. and Kroon, P. A. (2003). Profiling glucosinolates and phenolics in vegetative and reproductive tissues of the multipurpose trees Moringa oleifera L. (Horseradish tree) and Moringa stenopetala L. Journal of Agriculture and Food Chemistry 51(12): 3546-3553.

Bukar, A., Uba, A. and Oyeyi, T. I. (2010). Antimicrobal profile of Moringa oleifera Lam. Extracts against 
some food-borne microorganisms. Bayero Journal of Pure and Applied Sciences 3(1): 43-48.

Caceres, A., Cabrera, O., Morales, O., Mollinedo, P. and Mendia, P. (1991). Pharmacological properties of Moringa oleifera. 1: Preliminary screening for antimicrobial activity. Journal of Ethnopharmacology 33: 213-216.

Càceres, A., Saravia, A., Rizzo, S., Zabala, L., De Leon, E. and Nave, F. (1992). Pharmacologic properties of Moringa oleifera. 2: Screening for antispasmodic, antiinflammatory and diuretic activity. Journal of Ethnopharmacology 36: 233-237.

Chuang, P. H., Lee, C. W., Chou, J. Y., Murugan, M., Shieh, B. J. and Chen, H. M. (2007). In vitro antifungal activity of ethanolic extract of the leaves of Moringa oleifera against dermatophytes. Bioresources Technology 98: 232-236.

Dahot, M. U. (1998). Antimicrobial Activity of Small Protein of Moringa oleifera leaves. Journal of Islamic Academy of Sciences 11(1): 27-32.

Dangi, S. Y., Jolly, C. I. and Narayana, S. (2002). Anti hypertensive activity of the total alkaloids from the leaves of Moringa oleifera. Journal of Pharmaceutical Biology 2 (40): 144-148.

Doughari, J. H., Pukuma, M. S. and De, N. (2007). Antibacterial effects of Balanites aegyptiaca L. Drel. and Moringa oleifera Lam. on Salmonella typhi. African Journal of Biotechnology 6(19): 2212-2215.

Fahey, J. W., Dinkova-Kostova, A. T. And Talalay, P. (2004). The "Prochaska" microtiter plate bioassay for inducers of NQO1. Chapter 14 in Methods in Enzymology, Vol. 382, Part B, (Eds.) H. Sies \& L. Packer, Elsevier Science, San Diego, CA, pp. 243258

Faizi, S et al (1994). Novel hypotensive agents, niazimin $A$, niazimin $B$, niazicin $A$ and niazicin $B$ from Moringa oleifera: Isolation of first naturally occurring carbamates. Journal of Chemical Society Perkin Transactions 1: 3035-3040.

Faizi, S., Siddiqui, B. S., Saleem, R., Siddiqui, S., Aftab, K. and Gilani, A. H (1995). Fully acetylated carbamate and hypotensive thiocarbamate glycosides from Moringa oleifera. Phytochemistry 38(4): 957-963.

Fletcher, L. J. (1998). Moringa oleifera (the kelor tree). The Australian New Crops newsletter Issue No. 9: 1-6.

Fuglie, L. J. (2000). New Uses of Moringa Studied in Nicaragua. ECHO Development Notes \#68, June, 2000. Available from: http://www.echotech.org/ network/modules. php?name $=$ News\&file $=$ article\&sid $=$ 194. [Accessed December1, 2005]

Fuglie, L. J. (2001). The Miracle Tree. Moringa oleifera: Natural Nutrition for the Tropics. CWS, Dakar, Senegal. p.115.

Fuglie, L. J. (2005). The Moringa Tree: a local solution to malnutrition? ChurchWorld Service in Senegal. pp75.

Hukkeri, V. I., Nagathan, C. V., Karadi, R. V. and Patil, B. S (2006). Antipyretic and wound healing activities of Moringa oleifera Lam. in rats. Indian Journal of Pharmaceutical Science 68: 124-126.

Iwu, M. M. (2000). Empirical Investigation of Dietary Plants used in Igbo Ethnomedicine: Vol 2, Cesta Press Enugu; Nigeria. pp. 4-5.

Jongrungruangchok, S., Bunrathep, S. and Songsak, T. (2010). Nutrients and minerals content of eleven different samples of cultivated Moringa oleifera in Thailand. Journal of Health Research 24(3): 123-127.

Majorie, M. C. (1999). Plant products as antimicrobial agents. Clinical Microbiology Review 12(4): 564-582.

Medhi, B., Khanikor, H. N., Lahon, L. C., Mohan, P. and Barua, C. C. (1996). Analgesic, Antiinflammatory and Local Anaesthetic Activity of Moringa pterygosperma in Laboratory Animals. International Journal of Pharmacognosy 34(3): $207-$ 212.

Mishra, G., Singh, P., Verma, R., Kumar, S., Srivastav, S., Jha, K. And Khosa, R. L. (2011). Traditional uses, phytochemistry and pharmacological properties of Moringa oleifera plant: An overview. Scholars Research Library Der Pharmacia Lettr 3(2): 141-164.

Murakami, A., Kitazono, Y., Jiwajinda, S., Koshimizu, K. and Ohigashi, H. (1998). Niaziminin, a thiocarbamate from the leaves of Moringa oleifera, holds a strict structural requirement for inhibition of tumor-promoter- induced Epstein-Barr virus activation. Planta Medica 64(4): 319-323.

Nwosu, M. O. and Okafor, J. I. (1995). Preliminary studies on the antifungal activities of some medicinal plants against Basidiobolus and some other pathogenic fungi. Mycoses 38(5-6): 191-195.

Oduro, I., Ellis, W. O. and Owusu, D. (2008). Nutritional potential of two leafy vegetables: Moringa oleifera and Ipomoea batatas leaves. Scientific Research and Essays 3 (2): 057-060.

Olson, M. E. (2002). Amplified fragment length polymorphism (AFLP) analysis of genetic variation in Moringa oleifera Lam. Molecular Ecology 8(3): 463470.

Oluma, H. O., Umeh, E. U., Onekutu, A. and Okolo, J. (2004). Antibacterial potentials of eight medicinal plants from the lower Benue valley of Nigeria. Nigerian Journal of Botany 17: 1-11.

Price, M. L. (1985). The Moringa Tree. ECHO Technical Note. Educational Concerns for Hunger Organization, N. Ft. Meyers, FL. Available at: http://www.echotech.org/technical/technotes/moringa biomasa.pdf.

Rahman, M. M., Islam, M. M., Sheikh, S. A., Sharmin, A., Islam, M. S., Rahman, A., Mizanur Rahman, M. and Alam, M. F. (2009). Antibacterial Activity of Leaf Juice and Extracts of Moringa oleifera Lam. against Some Human Pathogenic Bacteria. CMU Journal 8(2): 219-228.

Rathi, B. S., Bodhankar, S. L. and Baheti, A. M. (2006). Evaluation of aqueous extract of Moringa oleifera for wound healing in albino rats. Indian Journal of Experimental Biology 44:898-901. 
Rios, J. L., Recio, M. C. and Villar, A. (1998). Screening methods for natural products with antimicrobial activity: A review of the Literature. Journal of Ethnopharmacology 23:177-49.

Siddhuraju, P. and Becker, K. (2003). Antioxidant properties of various solvents extracts of total phenolic constituents from three different agroclimatic origins of drumstick tree (Moringa oleifera Lam.). Journal of Agriculture and Food Chemistry 51(8): 2144-2155.

Singh, B. N., Singh, B. R., Singh, R. L., Prakash, D., Dhakarey, R., Upadhyay, G. and Singh, H. B. (2009). Oxidative DNA damage protective activity, antioxidant and anti-quorum sensing Potentials of Moringa oleifera. Food Chemistry and Toxicology 47: 1109-1116.

Sofowora, E. A. (1982). Medicinal Plants and Traditional Medicine in African. Chichester, John Willey and Sons, London. pp. 109-111.

Sofowora, E. A. (1983). Medicinal Plants and Traditional Medicine in Africa, Second Edition John Willey and Sons, London. pp. 186-256.

Sofowora, E. A. (1984). Medicinal and Traditional Medicine in Africa. John Wiley and Sons, London. p. 249.

Sofowora, E. A. (1989). Traditional medicine and medicinal plants of Africa. Spectrum books Ltd. Ibadan, Nigeria. pp. 150-153.

Sofowora, E. A. (1993). Medicinal plants and Traditional medicine in Africa. Spectrum Books Ltd, Ibadan, Nigeria. pp. 289.

Sreelatha, S. and Padma, P. R. (2009). Antioxidant activity and total phenolic content of Moringa oleifera leaves in two stages of maturity. Plant Foods and Human Nutrition 64(4): 303-311.

Srinivasan, D., Perumalsamy, L. P., Nathan, S. and Sures, T. (2001). Antimicrobial activity of certain Indian medicinal plants used in folkloric medicine. Journal of Ethnopharmacology 94: 217-222.

Sultana, B., Anwar, F. and Ashraf, M. (2009). Antioxidant activity and total phenolic content of Moringa oleifera leaves. Molecules 14(6): 2167-2180.

Thilza, L. B., Sanni, S., Zakari, A. I., Sanni, F. S., Talle, M. And Joseph, B. M. (2010). In vitro Antimicrobial activity of water extract of Moringa oleifera leaf stalk on bacteria normally implicated in eye diseases. Academia arena 2(6): 80-82.

Trease, G. F. and Evans, W. C. (1978). A Textbook on Pharmacgnosy. Eleventh Edition, Baillere Trindal London. pp. 22-40.

Trease, G. E and Evans, M. D. (1989). A Textbook of Pharmacognosy. Builler Tindall and Caussel, 13th ed., London. pp. 176-180. 